\title{
Male Fertility as a Bull's Eye for Mastocytosis
}

\author{
Ali Shalizar Jalali* \\ Department of Basic Sciences, Urmia University, Iran \\ Submission: December 18, 2017; Published: February 21, 2018 \\ *Corresponding author: Ali Shalizar Jalali, Histology and Embryology Research Laboratories, Department of Basic Sciences, Faculty of Veterinary \\ Medicine, Urmia University, Urmia, Iran, Tel: 00984431942593; Fax: 00984432771926; Email: ali_shalizar@yahoo.com,a.shalizar@urmia.ac.ir
}

Keywords: Mast Cell, Male Infertility, Spermatogenesis, Oxidative Stress

Abbreviations: MC: Mast Cell; ICs: Immune Cells; ROS: Reactive Oxygen Species

\section{Opinion}

Mast cell (MC) as a free cell type can be found in connective and epithelial tissues throughout the body as well as peritoneal and thoracic cavities in rodents [1].The MCs are located in subepithelial areas in connective tissue surrounding blood cells, smooth muscle, mucous and hair follicles and have been detected in all vascularized tissues except for the central nervous system and the retina [2]. The cytoplasm of MC contains 50200 large granules storing a variety of substances with potent physiological activities including histamine, heparin, serotonin, cytokines, chondroitin sulfate and neutral proteases [3-5]. It is well-established that these multi-functional master cells are involved in a wide spectrum of functions including vasodilation, angiogenesis, bacterial and parasite elimination, immune system, vascular and bronchial homeostasis and bone growth, remodeling and mineral homeostasis along with inflammatory, hypersensitivity and fibrotic disorders [2, 6-8].Three populations of MCs have been identified based on protease content. The mucosal MC (MCT) only containstryptase, the connective tissue MC (MCTC) contains tryptase, chymase, carboxypeptidase and cathepsin and the third MC type (MCC) has chymase and carboxypeptidase [9].

A growing body of evidence indicates association between mastocytosis and male infertility [10-12]. It has been reported that increased number of MCs is ascribed to idiopathic male infertilities and spermatogenic disorders [13-15]. Accordingly, it has been revealed that number of MCT and MCTC increases in the testes of patients with spermatogenic arrest and Sertoli-cell-only syndrome, confirming MCs roles in the male infertility pathogenesis [16-18]. It has also been shown that increased numbers of MCs are associated with different types of spermatological abnormalities including asthenospermia, oligospermia, azoospermia and sperm DNA damages [19-21].
It has been suggested that paracrine factors from myoid, Sertoli and spermatogenic cells can play crucial roles in testicular mastocytosis [19]. Myoid cells may also trigger MCs activation through formation of membrane-to-membrane connections [16]. It is well-known that MC products can stimulate fibroblast migration, proliferation and synthesis of extracellular matrix compounds leading to tissue fibrosis [22]. On the other hand, increased depositions of fibrous connective tissue in the peritubular layers and thickening of the tubular wall have been attributed to several testicular pathological patterns resulting in male infertilities [23].

Additionally, MCs degranulation in response to biochemical stresses can lead to release of histamine and chemotactic factors causing increased vascular permeability and immune cells (ICs) infiltrations [24]. It is noteworthy to mention that ICs are sources of reactive oxygen species (ROS) production and excessive ROS generation induced oxidative stress is one of the major causative factors of reproductive dysfunctions [25-27]. Moreover, it was found that testicular mastocytosis is associated with blood-testis barrier malfunction [28]. In line with that, previous reports have shown the beneficial effects of MC blockers in improvement of male fertility impairments. Recently, it has been demonstrated that Ketotifen can improve sperm motility in asthenospermic infertile men and sperm quality, chromatin integrity and pregnancy rate after varicocelectomy [20]. Furthermore, it has been suggested that tranilast is clinically useful for the treatment of severe idiopathic oligozoospermia [29]. On the whole, mastocytosis in reproductive tract can result in male fertility disturbance through fibrotic changes and oxidative stress inductions as well as inflammatory responses formation and medicinal strategies such as administration of MC blockers may be beneficial in treatment of idiopathic male infertilities (Figure 1). 


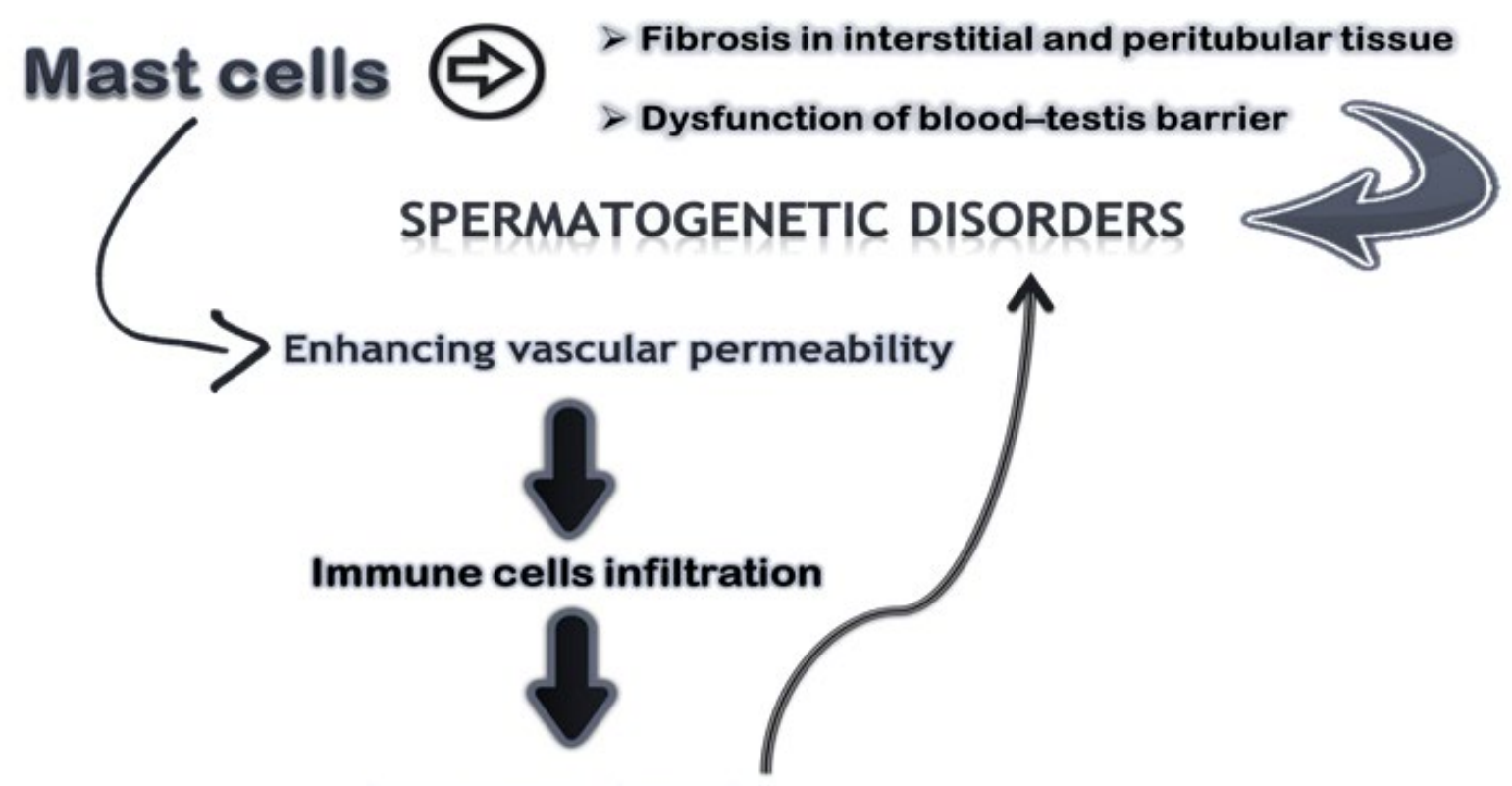

OXIDATIVE STRESS

Figure 1: Role of mast cells in spermatogenic disorders.

\section{References}

1. da Silva EZ, Jamur MC, Oliver C (2014) Mast cell function: a new vision of an old cell. J Histochem Cytochem 62(10): 698-738.

2. Krystel WM, Dileepan KN, Wood JG (2015) Mast cell: a multi-functional master cell. Front Immunol 6: 620.

3. Ishizaka T, Adachi T, Chang TH, Ishizaka K (1977) Development of mast cells in vitro II. Biologic function of cultured mast cells. J Immunol 118(1): 211-217.

4. Metcalfe DD, Baram D, Mekori YA (1977) Mast cells. Physiol Rev 77(4): 1033-1079.

5. Fijak M, Meinhardt A (2006) The testis in immune privilege. Immunol Rev 213: 66-681.

6. Yong LC (1977) The mast cell: origin, morphology, distribution, and function. Exp Toxicol Pathol 49(6): 409-424.

7. Benoist C, Mathis D (2002) Mast cells in autoimmune disease. Nature 420: 875-878.

8. Bulfone Paus S, Bahri R (2015) Mast cells as regulators of $\mathrm{T}$ cell responses. Front Immunol 6: 394.

9. Welle M (1997) Development, significance, and heterogeneity of mast cells with particular regard to the mast cell-specific proteases chymase and tryptase. J LeukocBiol 61(3): 233-245.

10. Maseki Y, Miyake K, Mitsuya H, Kitamura H, Yamada K(1981) Mastocytosis occurring in the testes from patients with idiopathic male infertility. Fertil Steril 36(6): 814-817.

11. Agarwal S, Choudhury M, Banerjee A (1987) Mast cells and idiopathic male infertility. Int J Fertil 32(4): 283-286.

12. Kollur SM, Pattankar VL, El Hag IA (2004) Mast cells in testicular lesions. Ups J Med Sci 109(3): 239-245.

13. Hashimoto J, Nagai T, Takaba H, Yamamoto M, Miyake K(1983) Increased mast cells in the limiting membrane of seminiferous tubules in testes of patients with idiopathic infertility. Urol Int 43(3): 129-132.
14. Nagai T, Takaba H, Miyake K, Hirabayashi Y, Yamada K (1992) Testicular mast cell heterogeneity in idiopathic male infertility. Fertil Steril 57(6): 1331-1316.

15. Hussein MR, Abou-Deif ES, Bedaiwy MA, Said TM, Mustafa MG, et al. (2005) Phenotypic characterization of the immune and mast cell infiltrates in the human testis shows normal and abnormal spermatogenesis. Fertil Steril 83(5): 1447-1453.

16. Jezek D, Banek L, Hittmair A, Panijan PR, Goluza T, et al. (1993) Mast cells in testicular biopsies of infertile men with 'mixed atrophy' of seminiferous tubules. Andrologia 31(4): 203-210.

17. Meineke V, Frungieri MB, Jessberger B, Vogt H, Mayerhofer A (2000) Human testicular mast cells contain tryptase: increased mast cell number and altered distribution in the testes of infertile men. Fertil Steril 74(2):239-244.

18. Yamanaka K, Fujisawa M, Tanaka H, Okada H, Arakawa S, et al. (2000) Significance of human testicular mast cells and their subtypes in male infertility. Hum Reprod 15(7): 1543-1547.

19. Roaiah MM, Khatab H, Mostafa T (2007) Mast cells in testicular biopsies of azoospermic men. Andrologia 39(5):185-189.

20. Azadi L, Abbasi H, Deemeh MR, Tavalaee M, Arbabian M, et al. (2011) Zaditen (Ketotifen), as mast cell blocker, improves sperm quality, chromatin integrity and pregnancy rate after varicocelectomy. Int J Androl 34(5 Pt 1): 446-452.

21. Saharkhiz N, Nikbakht R, Hemadi M (2013) Ketotifen, a mast cell blocker improves sperm motility in asthenospermic infertile men. J Hum Reprod Sci 6(1): 19-22.

22. Frungieri MB, Weidinger S, Meineke V, Köhn FM, Mayerhofer A (2002) Proliferative action of mast-cell tryptase is mediated by PAR2, COX2, prostaglandins, and PPARgamma: Possible relevance to human fibrotic disorders. Proc Natl Acad Sci U S A 99(23): 15072-15077.

23. Montella A, Pirino A (1992) Morphological characteristics of mastocytes in the infertile human testicle. Boll Soc Ital Biol Sper 68(2): 77-84.

24. Stone KD, Prussin C, Metcalfe DD (2010). IgE, mast cells, basophils, and eosinophils. J Allergy Clin Immunol 125(2 Suppl 2): S73-S80. 
25. Mittal M, Siddiqui MR, Tran K, Reddy SP, Malik AB (2014) Reactive oxygen species in inflammation and tissue injury. Antioxid Redox Signal 20(7): 1126-1167.

26. Makker K, Agarwal A, Sharma R (2009) Oxidative stress and male infertility. Indian J Med Res 129(4): 357-367.

27. Bisht S, Faiq M, Tolahunase M, Dada R (2017) Oxidative stress and male infertility. Nat Rev Urol 14(8): 470-485.

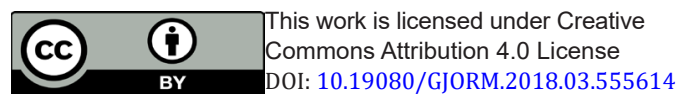

28. Haidl G, Duan YG, Chen SJ, Kohn FM, Schuppe HC, et al. (2011) The role of mast cells in male infertility. Expert Rev Clin Immunol 7(5): 627-634.

29. Hibi H, Kato K, Mitsui K, Taki T, Yamada Y, et al. (2001)The treatment with tranilast, a mast cell blocker, for idiopathic oligozoospermia. Arch Androl 47(2): 107-111.

Your next submission with Juniper Publishers
will reach you the below assets
- Quality Editorial service
- Swift Peer Review
- Reprints availability
- E-prints Service
- Manuscript Podcast for convenient understanding
- Global attainment for your research
- Manuscript accessibility in different formats
( Pdf, E-pub, Full Text, Audio)
- Unceasing customer service
Track the below URL for one-step submission
https://juniperpublishers.com/online-submission.php

